\title{
Talent Management is the Future Challenge for Healthcare Managers for Organizational Success
}

\author{
Dr. Eman Salman Mohamed Salman Taie ${ }^{1}$ \\ Assistant Professor of Nursing Administration, Head of Nursing Administration Department \\ Faculty of Nursing- Helwan University.
}

\begin{abstract}
:
Background- Talent management is an ongoing, proactive activity it is about attracting, identifying, recruiting, developing, motivating, promoting and retaining people that has a strong potential to succeed within an organization. In a competitive marketplace, talent management is a primary driver for organizational success.
\end{abstract}

Aim- To explore the association between talent management elements and organizational success.

Method- It was a quasi- experimental study. The study was conducted in three hospitals (Ain Shams Specialized hospital, El-Nasr and el-Salam Hospitals). The study subjects consisted of three levels of nurse managers. Data was collected by using three questionnaires (nurse managers' knowledge about talent management, talent management elements and organizational success).

Results- There was a high significant different $(p<0.001)$ between nurse managers' knowledge about talent management before and after awareness sessions. Also the different was high significant between the three of the studied hospitals concerning results of talent management elements.

Conclusion- There was strong positive $(r=0.89 *)$ correlation among the talent management elements and organizational success scores.

Keywords: Talent, Talent Management, Organization, Success, Future Success.

\section{INTRODUCTION}

Today's markets have become global and highly competitive. Therefore, it has become essential for the survival of the firms they become adaptive and responsive to change around them. In essence, the talented people are an asset for any organization and behind the success of the organizations.(Abbasi et.al., 2013). Organizations have to attract, develop and retain their talented employees and as long as possible, especially those who are extraordinary talented (Mohamadzadeh, Mohamadzadeh \& Haghparast, 2012). In today's dynamic world full of change, organizations must undergo in order to adapt to environmental change and grow and reach higher levels of production. Organizations for growth and change need ongoing production's methods and processes, products and services, to increase innovation in the market place to find the most suitable place to achieve (Dehkordy, Haydari \& Iravani, 2014).

There are so many demands for time and resources, healthcare managers will continue to find it necessary to focus their attention on the solutions and processes that can have the biggest impact on their organization. Talent management reaches beyond the human resources department and impacts the healthcare organization's ability to achieve their corporate goals (Zhang \& Bright, 2012). Employees are the lifeblood of a healthcare organizations and the development of those valuable human resources are critical to the short-term and long-term success of the entire health system. When the talent pool within the organization is nurtured effectively, employee satisfaction increases, labor costs are reduced and patient care improves. Talent management strategies and solutions that lead to talent optimization empower healthcare executives to improve both clinical and financial outcomes now and in the future (Tiwari \& Sherivastava, 2013).

Talent has become the key differentiator for human capital management, and the management of talent seems to be one of the key functions that human recourses management is playing strategically in organizations (Stadler, 2011). There are several definitions of the term talent according to the field of work. The commonest way to define talent is

${ }^{1}$ Corresponding Author: Dr_emys@hotmail.com 
by making reference to an individual's performance, authors note that most managers have a tendency to define talent in terms of outcomes. (Zhang \& Bright, 2012). Talent refers to unique characteristics, qualities, traits or abilities of people who utilize this to reach the objectives of organizations (El Nakhla, 2013).

Talent Management has recently received most attention; it is not just a new fancy word for finding and developing employees. Talent management is an ongoing, proactive activity it is about attracting, identifying, recruiting, developing, motivating, promoting and retaining people that has a strong potential to succeed within an organization (Rothwell, 2012). Talent management is the implementation of "initiatives and strategies to harness the unique talents of individual employees and convert their talent potential into optimum organization performance" (Abbasi et.al., 2013).

Talent Management is considered as a human resource management process organizations must overcome and systematically eliminate the gap between the skills and talents needed to achieve the targets (EI Nakhla, 2013). Organizational talent management is hiring the right people at the right time appropriate. (Dodova \& Harvathova, 2010) Talent management is workforce planning and analysis of the hiring process, training and development practices and keeping the talent and success of the program covers.. In other words, talent management means workforce supply and demand of underway processes (Zhang \& Bright, 2012).

\section{SIGNIFICANCE OF THE STUDY}

There is a war going on, and many healthcare organizations are fighting it and losing. It is the war to attract and retain great talent. The need to enhance the success of the organization lies in the heart of the management of the firm. There are several resources to achieve this which include money, men and the machine, but the most important of these resources is men. Organizations know that they must have the best talent in order to succeed in the hypercompetitive and increasingly complex global economy (Stahl et al., 2012). In a competitive marketplace, talent management is a primary driver for organizational success. Broadly defined talent management is the implementation of integrated strategies or systems designed to increase workplace productivity by developing improved processes for attracting, developing, retaining and utilizing people with the required skills and aptitude to meet current and future organization's needs (Hamidi, Saberi \& Safari, 2014).

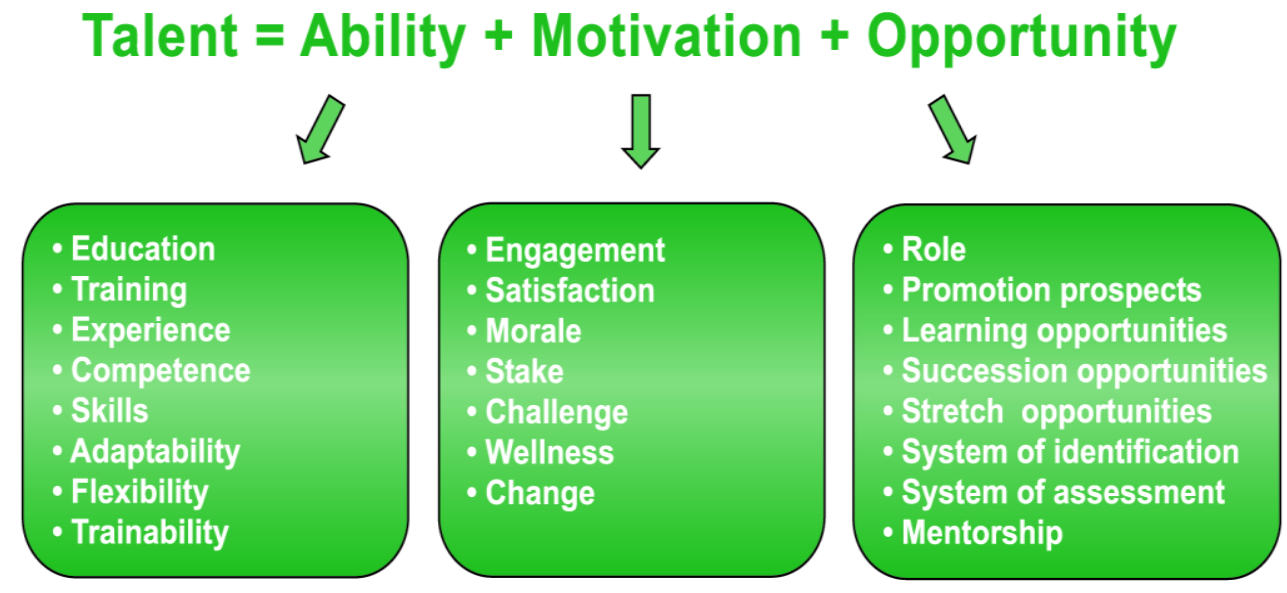

Fig1. Components of Talent

\subsection{Aim of the Study}

The present study aims to explore the association between talent management elements and organizational success through:

1. Assess nurse managers' knowledge about talent management in the selected hospitals.

2. Increase nurse managers' awareness about talent management.

3. Assess talent management elements in the selected hospitals.

4. Investigate association between talent management elements and organizational success. 
American Research Journal of Nursing, Volume 1, Issue 1, 2015

ISSN 2379-2922

\subsection{Research hypotheses}

It was hypnotized that all of nurse managers lack knowledge about talent management, there will be a positive correlation between talent management elements and organizational success.

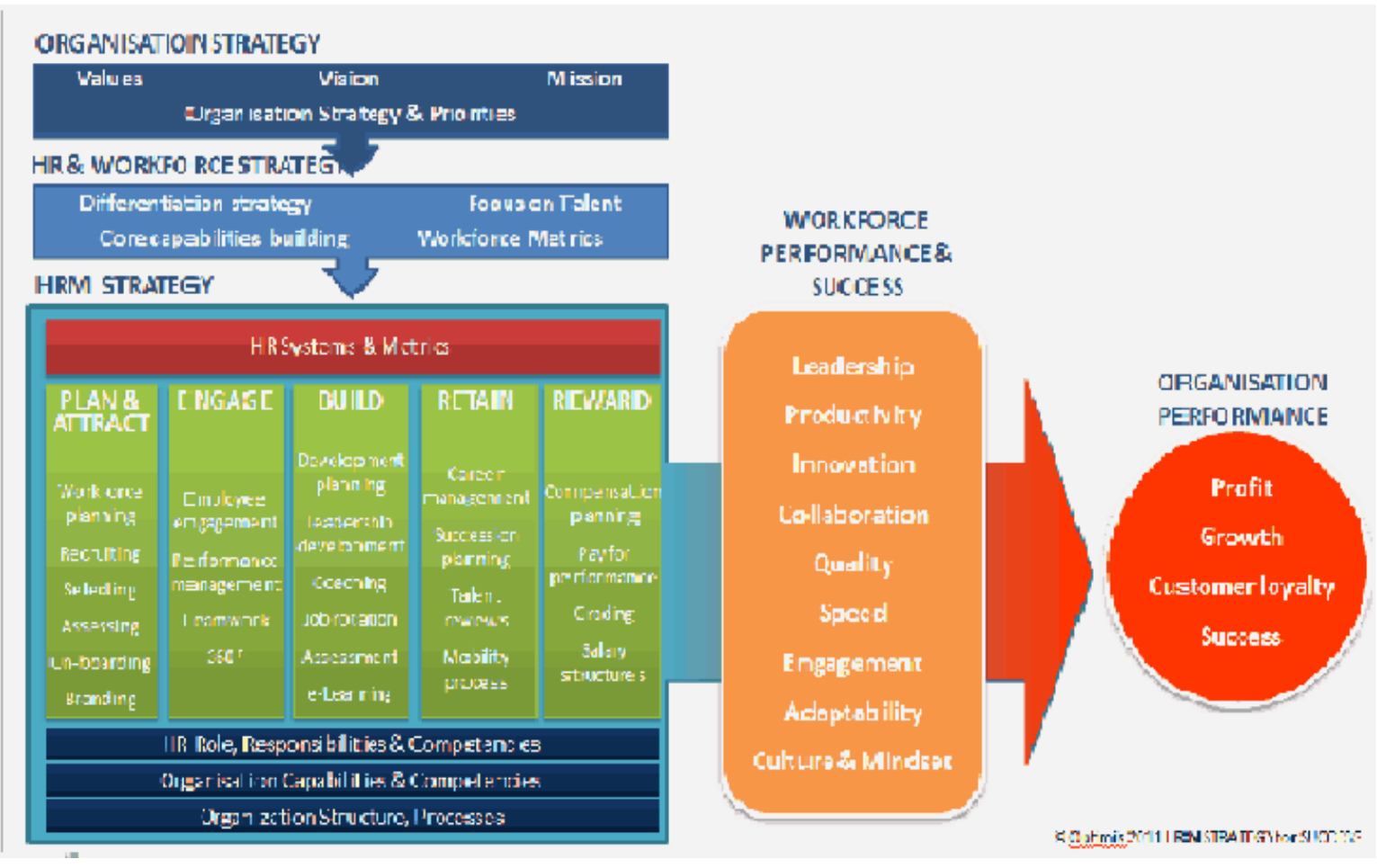

Fig2. Human Resource Management Strategy For Success (Optimis 2011)

\subsection{Subjects and Methods}

\subsubsection{Research design}

It is a quasi- experimental study.

\subsubsection{Study setting}

The study was conducted in one University hospitals (Ain Shams Specialized Hospital), also in one Health Insurance Hospitals (El-Nasr Hospital affiliated to health insurance sector in Helwan governorate) and one private hospital (El Salam Hospital).

\subsubsection{Subjects}

The study subjects consisted of three levels of management: top management, middle and functional management $\left(1^{\text {st }}\right.$ line manager). All available nurse managers with at least two years experience were included in the study.

\section{DISTRIBUTION OF STUDY SAMPLES ACCORDING TO HOSPITALS}

\begin{tabular}{|c|c|c|c|c|c|c|}
\hline \multirow{3}{*}{ Hospital } & \multicolumn{6}{|c|}{ Management Levels (n=75) } \\
\hline & \multicolumn{2}{|c|}{ Top } & \multicolumn{2}{|c|}{ Middle } & \multicolumn{2}{|c|}{ First line Managers } \\
\hline & No. & $\%$ & No. & $\%$ & No. & $\%$ \\
\hline \multicolumn{7}{|l|}{ University } \\
\hline Ain Shams Specialized Hospital & 3 & 4.00 & 15 & 20.00 & 42 & 56.00 \\
\hline \multicolumn{7}{|l|}{ Health Insurance } \\
\hline El-Nasr & 6 & 8.00 & 4 & 5.33 & 13 & 17.33 \\
\hline \multicolumn{7}{|l|}{\begin{tabular}{|l|} 
Private \\
\end{tabular}} \\
\hline El Salam & 4 & 5.33 & 12 & 16.00 & 20 & 26.67 \\
\hline
\end{tabular}




\subsection{Tools of data collection}

\subsubsection{Nurse managers' knowledge about talent management questionnaire format}

This tool developed by the researcher after reviewing the relevant literature. It was used to assess the selected nurse managers' knowledge about talent management. It included questions as definition of talent management, its importance, its key components of a highly effective talent management process. The last question was an open ended question for mentioning reasons for not using talent management. It was reviewed by experts in the related field, and modifications were made based on their suggestions. The Cronbach Alpha coefficient of the instrument was 0.88 for the study sample. The instrument had high construct validity (with a part-whole correlation of 0.90). It was self-administered questionnaire.

\subsubsection{Talent Management Elements Questionnaire}

This tool was developed by (Sibosiso in South Africa 2007). It included 60 questions. It assesses each element of talent management, and answers of test is set on likert's 5 values scale. The items of it include sub - scales that are: talent management planning system, talent management practice, organizational talent identification, organizational assessment, motivation factor and performance management.

\subsection{Act judgments were scored as follows}

Excellent: 4

$>$ Very good: 3

> Good: 2

$>$ Faire: 1

$>$ Poor: 0

\subsection{Scoring of the talent management elements questionnaire}

The total score for this scale was 60. It was divided into three levels as follow;

Low score level: less than 30

$>$ Moderate score level: ranged (31-45).

$>$ High score level: ranged (46-60).

It was reviewed by experts in the related field, and modifications were made based on their suggestions. The Cronbach Alpha coefficient of the instrument was 0.87 for the study sample. The instrument had high construct validity (with a part-whole correlation of 0.92). It was self-administered questionnaire.

\subsubsection{Organizational Success Questionnaire}

This tool was developed by the researcher based on review of current literature. It was used to indicate important dimensions of organizational success. Each respondent is asked to rate each item on likert's 5 values scale.

\subsection{Act judgments were scored as follows}

Strongly disagree: 1

$>$ Disagree: 2

$>$ Undecided: 3

$>$ Agree: 4

$>$ Strongly agree: 5

\subsection{Scoring of the Organizational Success questionnaire}

The total score for this scale was 100. It was divided into three levels as follow:

It was divided into three levels as follow;

a) Low score level: less than 60

b) Moderate score level: ranged (61-74).

c) High score level: ranged (75-100).

It was reviewed by experts in the related field, and modifications were made based on their suggestions. The Cronbach Alpha coefficient of the instrument was 0.88 for the study sample. The instrument had high construct validity (with a part-whole correlation of 0.91). It was self-administered questionnaire. 


\subsubsection{Pilot study}

The aim of the pilot study was to test the practicability, and to estimate the time required to complete tools. The researcher randomly selected 12 managers from Ain Shams Specialized Hospital, 7 from El-Nasr hospital and 10 from El-Salam hospital, from different management levels. The time needed to fulfill $1^{\text {st }}$ questionnaire format ranged between (15-20) minutes. While it was ranged between (20-30) minutes for the second one and ranged between (10-15) minutes for the last questionnaire. Collecting pilot study data lasts for one month. All of these subjects were included in the main study sample. Necessary modifications were done in the study tools according to pilot results.

\subsubsection{Field work}

The field work of this study was executed for one year. Data collection began on mid of June 2014 and was completed February 28, 2015. The researcher started to use the developed tools with selected sample participants in their settings according to the available time for each of them after explaining to them the purpose of the study. The $1^{\text {st }}$ tool was to assess nurse managers' knowledge about talent management, this was lasted for two months. Then, the awareness sessions were given to nurse managers five hours per day for two days, every awareness session was included (18-20) nurse manager. Awareness sessions were conducted one time per week and lasted for twelve weeks. Then, they were assessed again post awareness sessions. Finally, both the $2^{\text {nd }}$ and $3^{\text {rd }}$ tools were used . That lasted for four months.

\subsubsection{Administrative and Ethical Considerations}

To carry out the study in the predetermined hospitals, letters containing the aim of the study were directed from the researcher' faculty of nursing to hospitals' directors and also to nursing directors to obtain their permission and help to conduct the study in their facility. The researcher then met the hospitals directors and the nursing directors and explained the purpose and methods of data collection for the study. The researcher also obtained study subjects' approval orally after explaining the purpose and method of data collection for the study. Confidentiality, anonymity and the right to withdraw from the study at any time were guaranteed.

\subsection{Statistical Analysis}

Data entry and analysis was done using SPSS 13.0 statistical software package. Pearson correlation analysis was used for assessment of the inter-relationships among quantitative variables. Statistical significance was considered at p-value $<0.05$.

\section{RESULTS}

Table (1) displays nurse managers' knowledge about talent management before and after awareness sessions. It shows that all of them in the three of the studied hospitals were not aware of the complete definition, who are talented people?, talent management objectives, talent management process, key talent management activities and steps to effective talent management before awareness sessions. Meanwhile post awareness sessions the highest percentage of them became completely aware of the mentioned items. There was a high significant $(\mathrm{p}<0.001)$ difference between nurse managers' knowledge about talent management before and awareness sessions.

While, concerning results of talent management elements for all of the studied hospitals table (2) revealed that it was moderate score in ASSH, while it was low in El-Nasr hospital and high in El-Salam hospital. The difference was statistically significant $(\mathrm{p}<0.001)$ between the three of the studied hospitals.

Table (3) illustrates organizational success for all of the studied hospitals. It was high score in ASSH and El-Salam hospitals, while it was low score in El-Nasr hospital. There was a high significant $(\mathrm{p}<0.001)$ difference between the three of the studied hospital.

Table (4) describes an ecological correlation matrix among mean scores of talent management elements and organizational success using mean scores of individual hospitals. It shows strong statistically significant positive correlations among the two parameters. There was a high significant $(\mathrm{p}<0.001)$ difference between them. 
American Research Journal of Nursing, Volume 1, Issue 1, 2015

ISSN 2379-2922

Table1. Nurse Managers' knowledge about talent management before and after awareness sessions

\begin{tabular}{|c|c|c|c|c|c|c|c|c|c|c|c|c|c|}
\hline \multirow{3}{*}{$\begin{array}{l}\text { Items } \\
\begin{array}{l}\text { Definition of } \\
\text { talent } \\
\text { management }\end{array}\end{array}$} & \multicolumn{6}{|c|}{ Hospitals (Before awareness sessions) } & \multicolumn{6}{|c|}{ Hospitals (After awareness sessions) } & \multirow[t]{3}{*}{ P-value } \\
\hline & \multicolumn{2}{|c|}{$\begin{array}{l}\text { Ain Shams } \\
\text { S H. } \\
(n=60)\end{array}$} & \multicolumn{2}{|c|}{$\begin{array}{l}\text { El-Nasr } \\
(n=23)\end{array}$} & \multicolumn{2}{|c|}{$\begin{array}{l}\text { El Salam } \\
(n=36)\end{array}$} & \multicolumn{2}{|c|}{$\begin{array}{l}\text { Ain Shams } \\
\text { S H. } \\
(n=60)\end{array}$} & \multicolumn{2}{|c|}{$\begin{array}{l}\text { El-Nasr } \\
(n=23)\end{array}$} & \multicolumn{2}{|c|}{$\begin{array}{l}\text { EI Salam } \\
(n=36)\end{array}$} & \\
\hline & No. & $\%$ & No. & $\%$ & No. & $\%$ & No. & $\%$ & No. & $\%$ & No. & $\%$ & \\
\hline $\begin{array}{l}\text { Complete } \\
\text { definition }\end{array}$ & 0 & 0 & 0 & 0 & 0 & 0 & 53 & 88.33 & 19 & 82.61 & 32 & 88.89 & $<0.001 * *$ \\
\hline $\begin{array}{l}\text { Incomplete } \\
\text { definition }\end{array}$ & 0 & 0 & 0 & 0 & 2 & 5.56 & 7 & 11.67 & 1 & 4.35 & 3 & 8.33 & $<0.001 * *$ \\
\hline $\begin{array}{l}\text { Wrong } \\
\text { definition }\end{array}$ & 4 & 6.67 & 0 & 0 & 7 & 19.44 & 0 & 0 & 3 & 13.04 & 1 & 2.78 & $<0.001 * *$ \\
\hline Do not Know & 56 & 93.33 & 23 & 100 & 27 & 75.00 & 0 & 0 & 0 & 0 & 0 & 0 & $<0.001 * *$ \\
\hline \multicolumn{14}{|c|}{ Who are Talented People? } \\
\hline know & 0 & 0 & 3 & 13.04 & 8 & 22.22 & 58 & 96.67 & 21 & 91.30 & 34 & 94.44 & $<0.001 * *$ \\
\hline Do not Know & 60 & 100 & 20 & 86.96 & 28 & 77.78 & 2 & 3.33 & 2 & 8.70 & 2 & 5.56 & $<0.001 * *$ \\
\hline \multicolumn{14}{|c|}{ Talent management objectives } \\
\hline Complete & 0 & 0 & 0 & 0 & 0 & 0 & 55 & 91.67 & 17 & 73.91 & 35 & 97.22 & $<0.001 * *$ \\
\hline Incomplete & 2 & 3.33 & 0 & 0 & 6 & 16.67 & 3 & 5.00 & 3 & 13.04 & 1 & 2.78 & $<0.001 * *$ \\
\hline Do not Know & 58 & 96.67 & 23 & 100 & 30 & 83.33 & 2 & 3.33 & 3 & 13.04 & 0 & 0 & $<0.001 * *$ \\
\hline \multicolumn{14}{|c|}{ Talent management process } \\
\hline Complete & 0 & 0 & 0 & 0 & 0 & 0 & 48 & 80.00 & 20 & 86.96 & 33 & 91.67 & $<0.001 * *$ \\
\hline Incomplete & 0 & 0 & 0 & 0 & 0 & 0 & 12 & 20.00 & 3 & 13.04 & 3 & 8.33 & $<0.001 * *$ \\
\hline Do not Know & 60 & 100 & 23 & 100 & 36 & 100 & 0 & 0 & 0 & 0 & 0 & 0 & $<0.001 * *$ \\
\hline \multicolumn{14}{|c|}{ Key talent management activities } \\
\hline Complete & 0 & 0 & 0 & 0 & 0 & 0 & 55 & 91.67 & 19 & 82.61 & 31 & 86.11 & $<0.001 * *$ \\
\hline Incomplete & 0 & 0 & 0 & 0 & 0 & 0 & 5 & 8.33 & 4 & 17.39 & 5 & 13.89 & $<0.001 * *$ \\
\hline Do not Know & 60 & 100 & 23 & 100 & 36 & 100 & 0 & 0 & 0 & 0 & 0 & 0 & $<0.001 * *$ \\
\hline \multicolumn{14}{|c|}{ Steps to effective talent management } \\
\hline Complete & 0 & 0 & 0 & 0 & 0 & 0 & 49 & 81.67 & 17 & 73.91 & 33 & 91.67 & $<0.001 * *$ \\
\hline Incomplete & 0 & 0 & 0 & 0 & 0 & 0 & 7 & 11.67 & 5 & 21.74 & 3 & 8.33 & $<0.001 * *$ \\
\hline Do not Know & 60 & 100 & 23 & 100 & 36 & 100 & 4 & 6.67 & 1 & 4.35 & 0 & 0 & $<0.001 * *$ \\
\hline
\end{tabular}

(*) statistically significant at $p<0.05$

(**) high statistically significant at $p<0.001$

Table 2. Talent Management Elements score in different hospitals

\begin{tabular}{|c|c|c|c|c|c|c|c|}
\hline \multirow{3}{*}{$\begin{array}{c}\text { Talent Management } \\
\text { Elements }\end{array}$} & \multicolumn{6}{|c|}{ Hospitals } & \multirow[t]{3}{*}{ P-value } \\
\hline & \multicolumn{2}{|c|}{$\begin{array}{c}\text { Ain Shams S H. } \\
(n=60)\end{array}$} & \multicolumn{2}{|c|}{$\begin{array}{c}\text { El-Nasr } \\
(n=23)\end{array}$} & \multicolumn{2}{|c|}{ El Salam $(n=36)$} & \\
\hline & No. & $\%$ & No. & $\%$ & No. & $\%$ & \\
\hline - Low Scores & 11 & 18.33 & 17 & 73.91 & 3 & 8.33 & $<0.001 * *$ \\
\hline - Moderate Scores & 44 & 73.33 & 4 & 17.39 & 12 & 33.33 & $<0.001 * *$ \\
\hline - High Scores & 5 & 8.33 & 2 & 8.70 & 21 & 58.33 & $<0.001 * *$ \\
\hline
\end{tabular}

(*) statistically significant at $p<0.05$

(**) high statistically significant at $p<0.001$

Table3. Organizational Success scores in the different hospitals

\begin{tabular}{|c|c|c|c|c|c|c|c|}
\hline \multirow{3}{*}{$\begin{array}{l}\text { Organizational } \\
\text { Success }\end{array}$} & \multicolumn{6}{|c|}{ Hospitals } & \multirow[t]{3}{*}{ P-value } \\
\hline & \multicolumn{2}{|c|}{$\begin{array}{l}\text { Ain Shams S H. } \\
(n=60)\end{array}$} & \multicolumn{2}{|c|}{$\begin{array}{l}\text { El-Nasr } \\
(n=23)\end{array}$} & \multicolumn{2}{|c|}{ El Salam $(n=36)$} & \\
\hline & No. & $\%$ & No. & $\%$ & No. & $\%$ & \\
\hline
\end{tabular}


American Research Journal of Nursing, Volume 1, Issue 1, 2015 ISSN 2379-2922

\begin{tabular}{|l|l|l|l|l|l|l|l|}
\hline - Low Scores & 6 & 10.00 & 15 & 65.22 & 0 & 0.00 & $<0.001^{*}$ \\
\hline - Moderate Scores & 11 & 18.33 & 8 & 34.78 & 4 & 11.11 & $<0.001^{*}$ \\
\hline - High Scores & 43 & 71.67 & 0 & 0 & 32 & 88.89 & $<0.001^{*}$ \\
\hline
\end{tabular}

(*) statistically significant at $\mathrm{p}<0.05$

(**) high statistically significant at $\mathrm{p}<0.001$

Table4. Ecological correlation matrix (by hospitals) among mean scores of talent management elements and organizational success

\begin{tabular}{|l|l|l|}
\hline & \multicolumn{2}{|c|}{} \\
\cline { 2 - 3 } & Pearson Correlation coefficient & P-value \\
\hline Talent Management Elements & $0.89^{*}$ & 0.001 \\
\hline Organizational Success & & \\
\hline
\end{tabular}

(*) statistically significant at $p<0.05$

(**) high statistically significant at $p<0.001$

\section{DISCUSSION}

Talent management involves positioning the right people in the right jobs .This ensures that the employees maximize their talent for optimal success of the organization. Managing talent is a challenge to all organizations in the context of globalization irrespective of the country. However, the present study revealed that the majority of the study sample was not aware of the complete definition of talent management and talent management activities (Cappelli, 2008;Tansley, 2011). These findings were inconsistent with (Rothwell, 2012, Bersin, 2013) who stated that talent management is a systematic and dynamic process of discovering, developing and sustaining talent. This was supported by (Tiwari \& Sherivastava, 2013; Saberi \& Safari, 2014) who emphasized that talent management is concerned with the recruitment, selection, identification, retention, management, and development of personnel considered having the potential for high performance.

The war for talent, keep your talent, recruit talent. These have become buzzwords that most managers and human resource people throw around in most meetings. Talented workers are two to three times more productive than the average worker. The more of them you have in your organization the more productive and profitable your organization will be (Boudreau \& Ramstad 2005, Davies \& Davies 2010;Bersin 2013). These were contradicted with findings of the present study. On the same line (Hatum, 2010;Hamidi , Saberi \& Safari, 2014) stated that talented people are regularly demonstrate exceptional ability and achievement over a range of activities and transferable high competence. Also, they are high impact people who can deal with complexity. The purpose of talent management is to ensure that the right supply of talented workforce is ready to realize the strategic goals of the organization both today and in the future (Bersin 2013). The majority of the present study revealed that they not aware of the talent management objectives. These findings were inconsistent with (Stadler, 2011, Zhang \& Bright, 2012) who asserted that it helps organizations to compete effectively in a complex and dynamic environment to achieve sustainable growth and to empower employees. This was supported by (Stahl et al.,2012; Tiwari \& Sherivastava, 2013) who found that it cuts down on high turnover rates and reduces the cost of constantly hiring new people to train.

An underlying assumption is that the talent management assumes an organization as a whole. Certain stages of talent management are needed to achieve results that are described in the following steps: goal setting is the first step of talent management. Implementation of talent management in an organization needs to define the goals that are primarily accomplished through the answers to the questions of how and where this is done. The next step is determining main posts, and then determines features about employees or workers who are competent and ideal (Brewster, Sparow \& Haris, 2005;Collings \& Mellahi, 2009; Oehley \& Theron, 2010, El Nakhla, 2013; Dehkordy, Haydari \& Iravani, 2014). These features are defined as the knowledge, skills and experience and a focus on results. This followed by detecting potential employees which include recognition of talented employees, internal and external sources are considered. Then analyzing the deficiency and the gap between the workers recruited and planned. They added that in this step, quality of people who have been explained as the key issues and required quality is comparable shortcomings and gaps are identified. This is followed by designing and implementation of development programs. Finally evaluate employee' performance. The entire previous are contradicted with results of the present study.

When looking at developing talent within an organization, it is important to look at how this activity links with the operations of the health system. Talent identification, succession planning, and organization design assessments, which encompass the leadership, are directly linked to how work gets accomplished, how organizational strategy is 
defined and activated, and how a health system meets its financial commitments each year (Dordova $\&$ Harvathova, 2010; Rothwell, 2012). Results of the present study before awareness sessions revealed that all of the study sample lack knowledge about steps to effective talent management (Dordova \& Harvathova, 2010; Abbasi \& Rana, 2013). These findings were in contrast with (Bersin, 2013; Dehkordy, Haydari \& Iravani, 2014) who mentioned that if organizations are serious about improving operating margin, revenue, and efficiency, leaders must make an investment and commitment to spending $20 \%$ to $30 \%$ of their time developing their people in a formal process such as the leadership and talent review. They added that developing a cross-organization succession plan, beginning with high-risk positions, managers should build a pool of candidates suited to occupy these roles should they become vacant. On the same line (EI Nakhla, 2013) asserted that talent assessment should not be limited to Clevel positions, but rather a system wide initiative aimed at building strong managers, directors, and supervisors, starting as early as an individual's first year on the job. This was supported by (Abbasi et.al., 2013) who emphasized that the process of assessing talent should be diversified to ensure no "diamonds in the rough" are overlooked, it means to include all levels of management in the assessment process. (Mohamadzadeh, Mohamadzadeh \& Haghparast, 2012;Hamidi, Saberi \& Safari, 2014) asserted that assessing the organizational chart for gaps in leadership helps identify where new positions may be needed, and underscores the importance of developing talent who can step into more than one role if required. They also added that predictive workforce planning is a vital step. Finally getting started by building the road map, creating the tools and templates and keeping up the momentum.

In a competitive marketplace, talent management is a primary driver for organizational success. As a result of the dynamic demographic, economic and social changes the concept of talent management has become one of the most important topics in today's organizations. Organizations are beginning to realize that talent is a core competitive asset and a key factor of organizations' success (Lockwood, 2006; Haghparast, Moharamzadeh \& Mohamadzadeh, 2012). It has become obvious that talent management is one of the key challenges to the organizations in countries today and in the future. The present study emphasized that there were a positive correlation between talent management elements and organizational success. This was supported by (Haghparast, Mehrdad \& Hasan, 2012, Abbasi \& Rana, 2013) who found the same results. Regarding reasons for not using talent management in organizations the entire sample mentioned that most of the organizations are not familiar with it, they also stated that some organizations are familiar with it but it seems to be too demanding in terms of organizational work, have not to their disposal means financial or resources - personnel or both of them. Others asserted that organizations do not consider it as suitable to them. (Sibusiso, 2007; Dordova \& Harvathova, 2010; Schuler, Jackson \& Tarique, 2011) found the same results. While it was contradicted with (Bersin, 2013, Hamidi, Saberi \& Safari, 2014) who emphasized that acceleration of business changes, shift towards emerging markets, borderless workplace, new job and career models - more specialized and more contingent jobs need specialized and flexible career models, social reward programs, globalization, changing the world of work, demographic changes and facilitated talent mobility, twenty-first-century models of leadership and today's talent markets are highly competitive.

\section{CONCLuSION}

There was a high significant different $(\mathrm{p}<0.001)$ between nurse managers' knowledge about talent management before and after awareness sessions. Also the different was high significant between the three of the studied hospitals concerning results of talent management element There was strong positive $\left(r=0.89^{*}\right)$ correlation among the talent management elements and organizational success scores.

\section{RECOMMENDATIONS}

Based on the study findings, the following recommendations were suggested:

1. Health care organizations should introduce talent management strategy in their strategic planning to remain competitive in today's healthcare market.

2. Equip supervisors and managers in talent management skills so that they are better at motivating, coaching and developing the talent for example through training.

3. To create a talent management environment, organization must:

$>$ Define a clear vision for talent management;

$>$ Develop a roadmap for technology and process integration;

Apply robust technology to enable processes; and 
$>$ Prepare the workforce for change associated with the new environment.

4. Further research in this stream would strengthen a prescriptive theory about talent management, in the search for gaining sustainable competitive advantage.

\section{REFERENCES}

[1] Abbasi Abdu Sattar \& Rana Aiza (2013). Impact of Talant Management \& Employee Turnover Intention on Organizational Efficiency. Sci.Int. 25(3). 655-660.

[2] Abbassi Muhammad Arthar, Khalid Farah, Rehman Aziz, Riaz Tauheeda, Ajiab Muhammad (2013). Justicia Peploides : An Inevitable Source of Natural Anitoxidants of Relief From Oxidative Stress. IRJP 4(1). 274-279.

[3] Bersin, J. (2013). Predictions for 2013: Corporate Talent, Leadership and HR-Nexus of Global Forces Drives New Models for Talent. Bersin by Deloitte. Retrieved from http://www.ihrc.ch/wpcontent/uploads/2013/03/predictions-2013-final-1.pdf.

[4] Boudreau, J. W. \& M. Ramstad, P. M. (2005). Talentship and the New Paradigm for Human Resource Management: From Professional Practices to Strategic Talent Decision Science. Human Resource Planning. 28(2), 17-26.

[5] Brewster,C. Sparow, P. \& Haris, H. (2005). Towards a new model of globalizing of HRM. International Human Resource management. 16 (6), 949-70.

[6] Cappelli, P. (2008). Talent Management for the Twenty-First Century. Harvard Business Review. 86 (3), 74-81.

[7] Collings, D. G. \& Mellahi, K. (2009). Strategic talent management: A review and research agenda. Human Resource Management Review. 19(4), 304-313.

[8] Davies, B. \& Davies, B. J. (2010). Talent management in academies. The International Journal of Educational Management, 24(5), 418-426.

[9] Dehkordy Merdad, Haydari Hadi \& Iravani Mohammad (2014). Study of Factors Affecting on Talent Management Among Bank's Employees in Shahrekord. International Journal of Scientific Research. 8(2): 1-10.

[10] Dordova Irena \& Harvathova Petra (2010). The Level of Talent Management Usage at Human Resource Management in Organizations of the Moravian - Silesian Region.3(1). 58-67.

[11] El Nakhla Mohamad (2013). The Availability of Talent Management Components From Employees Prespectives. Thesis submitted to partial fulfilment of the requirements for the degree of Master of Business Administration. Islamic University of Gaza.

[12] Hamidi Nassir , Saberi Hassan and Safari Mohamad (2014). The Effect of Talent Management on Job Satisfaction Gavarnmental Organizations. Journal of Novel Applied Science. 3(1). 100-113.

[13] Haghparast Sakineh, Moharamzadeh Mehrdad and Mohamadzadeh Hasan (2012). Relationship between talent management and organizational success. International Research Journal of Applied and Basic Sciences. 3(12). 2424-2430.

[14] Hatum, A. (2010). Next generation talent management: Talent Management to Survive Turmoil. New York: Palgrave Macmillan.

[15] Lockwood, N. R. (2006). Talent Management: Driver for Organizational Success. HR Magazine. 51 (6), 1-11.

[16] Mohamadzadeh Hassan, Mohamadzadeh Mehrdad \& Haghparast Sakineh (2012).Relationship Between Talent Management and Organizational Success. International Research Journal of Applied and Basic Sciences 3(12). 2424-2430.

[17] Oehley, A. M. \& Theron, C. C. (2010). The development and evaluation of a partial talent management structural model. Management Dynamics. 19(3), 2-28.

[18] Rothwell, W. J. (2012). Talent Management: Aligning your organization with best practices in strategic and tactical talent management. Training \& Development. 39(1), 6-7.

[19] Schuler, R S., Jackson, S. E. \& Tarique, I. (2011). Global talent management and global talent challenges: Strategic opportunities for IHRM. Journal of World Business. 46(4), 506.

[20] Sibusiso Ntonga (2007). The impact of talent management practices on business performance. A research project submitted to the Gordon Institute of Business Science, University of Pretoria, in partial fulfilment of the requirements for the degree of Master of Business Administration. 
[21] Stadler, K. (2011). Talent reviews: The key to effective succession management. Business Strategy Series., 12(5), 264-271.

[22] Stahl, G., Björkman, I., Farndale, E., Morris, S., Paauwe, J. \& Stiles, P. (2012). Six principles of effective global talent management. MIT Sloan Management Review. 53(2), 25-32. Retrieved from http://search.proquest.com/docview/914408228?accountid=14965.

[23] Tansley, C. (2011). What do we mean by the term "talent" in talent management?. Industrial \& Commercial Training. 43(5), 266-274.

[24] Tiwari Usha and Sherivastava Devanshi (2013). Strategies \& Practicies of Talant Management \& Their Impact on Employee Retention \& Effectiveness. International Journal of Management. 2(4). 1-10.

[25] Zhang S. \& Bright, D. (2012). Talent definition and talent management recognition in Chinese private-owned enterprises. Journal of Chinese entrepreneurship. 4(2), 143-163 